\title{
UJI DAYA HAMBAT BAWANG HUTAN Eleutherine palmifolia DENGAN METODE EKSTRAKSI BERBEDA TERHADAP PERTUMBUHAN BAKTERI Aeromonas hydrophila
}

\author{
${ }^{1)}$ Safratilofa dan ${ }^{2)}$ Muhammad Sugihartono \\ Program Studi Budidaya Perairan, Fakultas Pertanian Universitas Batanghari \\ Jl. Slamet Riyadi, Broni Jambi, 36122. Telp. +6074160103 \\ ${ }^{1)}$ Email korespondensi : osa.safra@yahoo.com
}

\begin{abstract}
The purpose of this research is to know the difference of inhibitory power of onion (Eleutherine palmifolia) with different extraction method to Aeromonas hydrophila bacteria growth. Extraction method that done in this research there are four that is infusion, dekoksi, maserai with $96 \%$ alcohol and maceration with 96\% ethanol. The method used to look at the inhibitory power of E. palmifolia on the growth of A. hydrophila bacteria is the method of disc diffusion by looking at the inhibit zone results around the disc paper. The hypothesis proposed is the effect of inhibitory power of different methods of extracting E. palmifolia on the growth of A. hydrophila bacteria. The results showed the widest resistor zone found in the treatment of maceration with alcohol that is the amount of 3,5 $\mathrm{mm}$ Keywords : Inhibitory potential test, Extraction Method, Eleutherine palmifolia, Aeromonas hydrophila.
\end{abstract}

\begin{abstract}
Abstrak
Tujuan dari penelitian ini adalah untuk mengetahui perbedaan daya hambat bawang hutan (Eleutherine palmifolia) dengan metode ekstraksi berbeda terhadap pertumbuhan bakteri Aeromonas hydrophila. Metode ekstraksi yang dilakukan pada penelitian ini ada empat yaitu infusi, dekoksi, maserai dengan alkohol $96 \%$ dan maserasi dengan etanol 96\%. Metode yang digunakan untuk melihat daya hambat E. palmifolia terhadap pertumbuhan bakteri A. hydrophila adalah metode disc diffusion yaitu dengan melihat hasil zona hambat disekitar kertas cakram. Hipotesis yang diajukan yaitu adanya pengaruh daya hambat dari perbedaan metode ektraksi E. palmifolia terhadap pertumbuhan bakteri A. hydrophila. Hasil yang didapat menunjukkan zona hambat terluas terdapat pada perlakuan maserasi dengan alkohol yaitu sebesar 3,5 mm

Kata Kunci : Uji Daya Hambat, Metode Ekstraksi, Eleutherine palmifolia, Aeromonas hydrophila.
\end{abstract}




\section{PENDAHULUAN}

Pengembangan teknologi budidaya ikan secara intensif untuk meningkatkan hasil produksi dapat berakibat pada penurunan kualitas perairan, sehingga menyebabkan stress yang dapat berdampak pada serangan penyakit yang disebabkan oleh bakteri. Salah satunya bakteri patogen pada ikan adalah bakteri Aeromonas hydrophila.

Bakteri A. hydrophila merupakan penyebab penyakit Motile Aeromonas Septicaemia (MAS), hemorrhagic septicaemia, ulcer disease atau red-sore disease (Rey et al., 2009). A. hydrophila merupakan mikroorganisme perairan tawar maupun air laut yang bersifat patogen oportunistik (Yogananth et al. 2009). Infeksi $A$. hydrophila dapat menimbulkan wabah penyakit ikan budidaya dengan tingkat kematian yang tinggi yaitu dapat mencapai 80-100\% dalam kurun waktu singkat yakni 1-2 minggu (Lukistyowati dan Kurniasih, 2012).

Upaya pencegahan yang dapat dilakukan yaitu dengan penggunaan fitofarmaka, vaksin dan probiotik. Menurut BPPOM (2005), fitofarmaka memiliki beberapa keunggulan dibandingkan kegiatan pencegahan lainnya, yaitu dapat dibuat dengan teknik sederhana serta tidak menimbulkan kerusakan lingkungan untuk pemakaian dalam waktu yang lama.

Salah satu jenis fitofarmaka yang dapat digunakan adalah bawang hutan (Eleutherine palmifolia). Tanaman ini digunakan sebagai obat oleh masyarakat Sulawesi Tenggara. Tanaman ini banyak ditemukan di daerah Kalimantan sehingga disebut juga bawang dayak. Selain itu, dibeberapa daerah di Indonesia, tanaman ini juga dikenal dengan nama bawang mekah, bawang sabrang, bawang hantu, dan bawang arab (Naafi'ah, 2014).

Potensi ekstrak bawang hutan (E. palmifolia) sebagai obat herbal antimikroba telah terbukti dapat menghambat beberapa jenis bakteri dan jamur seperti Staphylococcus aureus (Ifesan et al., 2009; Puspadewi et al., 2013), Salmonella typhi (Naafi'ah, 2014), Streptococcus pyogenes (Kamillah, 2014) dan kapang Trichophyton rubrum (Puspadewi et al., 2013). Perbedaan bakteri yang digunakan akan menunjukkan hasil daya hambat yang berbeda (Kamillah, 2014).

Bawang hutan (E. palmifolia) mengandung golongan senyawa antimikroba seperti alkaloid, flavonoid, saponin, tannin, glikosid, tripenoid (Firdaus, 2014; Puspadewi et al., 2013), polifenol, kuinon, steroid monoterpenoid dan seskuiterpenoid (Puspadewi et al., 2013). Senyawa-senyawa aktif tersebut dapat dipisahkan dari tanamannya melalui proses yang disebut dengan ekstraksi. Ekstraksi adalah suatu cara pemisahan senyawa dari campurannya yang biasanya menggunakan pelarut tertentu dengan prinsip perbedaan kelarutan. Menurut Depkes RI (2000), ekstraksi adalah kegiatan penarikan kandungan kimia yang dapat larut sehingga terpisah dari bahan yang tidak dapat larut dengan pelarut cair. Setiap komponen yang terpisah mempunyai perbedaan kelarutan yang cukup besar dalam zat pelarut tersebut. Profil senyawa aktif dari ekstrak tumbuhan obat dapat dipengaruhi banyak faktor. Salah satunya adalah pemilihan metode ekstraksi. Metode yang berbeda akan menghasilkan profil kimia yang berbeda pula. 


\section{METODOLOGI PENELITIAN}

Penelitian dilaksanakan pada bulan Juni tahun 2017 di Laboratorim Kesehatan Ikan, Departemen Kelautan dan Perikanan, Institut Pertanian Bogor. Umbi bawang yang digunakan telah berumur 3-4 bulan pasca tanam atau yang sudah mengeluarkan bunga. Umbi bawang dayak dibersihkan, kemudian diiris tipis-tipis, selanjutnya dikeringkan dengan oven pada suhu $60^{\circ} \mathrm{C}$ selama 48 jam. Setelah dikeringkan di blender kemudian diayak sehingga dihasilkan bawang hutan dalam bentuk tepung.

Tepung diekstraksi dengan empat metode ekstraksi yaitu infusi, dekoksi, maserai dengan alkohol $96 \%$ dan maserasi dengan etanol 96\%. Metode infusi adalah dengan merendam tepung dalam air hangat selama 15 menit. Metode dekoksi adalah perebusan tepung selama 15 menit. Metode maserasi Tepung diekstraksi (maserasi) dengan alkohol 95\%, selanjutnya diaduk selama 15 jam menggunakan magnetic stirrer pada suhu ruang. Hasil ekstrak kemudian dipekatkan dengan evaporator vacum pada suhu $40^{\circ} \mathrm{C}$ dan dilanjutkan dengan penguapan di atas tangas air/hot plate dengan suhu $40^{\circ} \mathrm{C}$, hal yang sama dilakukan untuk metode maserasi etanol $96 \%$. Perbandingan tepung dengan masing-masing pelarut adalah $1: 2(\mathrm{w} / \mathrm{v})(500 \mathrm{~g}$ tepung : $1000 \mathrm{~mL}$ pelarut $95 \%)$.

Uji daya hambat ekstrak bawang hutan menggunakan metode disc diffusion untuk melihat hasil zona hambat disekitar kertas cakram. Biakan murni bakteri Aeromonas hydrophila diambil sebanyak 1 ose di kultur pada $25 \mathrm{ml}$ media Tryptic Soy Broth (TSB) kemudian di inkubasi dalam waterbath shaker pada suhu $37^{\circ} \mathrm{C}$ selama 24 jam. Suspensi bakteri dipindahkan ke dalam tabung corning $25 \mathrm{ml}$ dan disentrifuse dengan kecepatan $5.000 \mathrm{rpm}$ selama 10 menit. Sel bakteri dicuci dengan $25 \mathrm{ml}$ larutan fisiologis ( $\mathrm{NaCL}$ 0,85\%). Setelah dicuci dilakukan pengenceran berseri sehingga diperoleh kepadatan bakteri $10^{6} \mathrm{CFU} / \mathrm{ml}$ (penentuan kepadatan bakteri dilakukan dengan penghitungan metode hitungan cawan). Sebanyak $50 \mu \mathrm{l}$ suspensi bakteri disebar pada media Tryptic Soy Agar (TSA). Kertas cakram steril dicelupkan ke ekstrak bawang hutan kemudian ditempelkan pada media TSA yang telah disebar bakteri. Ulangi kembali pada masing-masing ekstrak yang lain dengan metode yang sama. Setiap ekstrak dilakukan pengulangan sebanyak empat kali. Selanjutnya diinkubasi selama 24 jam pada suhu $37^{\circ} \mathrm{C}$. Setelah diinkubasi dilakukan pengukuran diameter zona hambat.

Perlakuan yang diujikan pada penelitian ini dapat dilihat pada Tabel 1

Tabel 1. Uji Daya Hambat Ekstrak Bawang Hutan pada Bakteri A. hydrophila dengan Berbagai metode ektraksi

\begin{tabular}{cc}
\hline Perlakuan & Macam Ektraksi \\
\hline A & Ekstrak Bawang Hutan + infusi \\
B & Ekstrak Bawang Hutan + dekokosi \\
C & Ekstrak Bawang Hutan + maserasi alkohol 96\% \\
D & Ekstrak Bawang Hutan + maserasi etanol 96\% \\
K & Aquades \\
\hline
\end{tabular}

Penelitian ini menggunakan rancangan percobaan berupa Rancangan Acak Lengkap dengan empat ulangan. Data yang diperoleh dianalisis dengan 
menggunakan analisis ragam dengan tingkat kepercayaan 95\%. Untuk melihat perbedaan perlakuan maka dilakukan uji lanjut dengan uji Duncan's Multiple Range dengan menggunakan program komputer SPSS 16.

\section{HASIL DAN PEMBAHASAN}

Ekstraksi adalah kegiatan penarikan kandungan kimia yang dapat larut sehingga terpisah dari bahan yang tidak dapat larut dengan pelarut cair (Depkes RI, 2000). Setiap komponen yang terpisah mempunyai perbedaan kelarutan yang cukup besar dalam zat pelarut tersebut. Profil senyawa aktif dari ekstrak tumbuhan obat dapat dipengaruhi banyak faktor. Salah satunya adalah pemilihan metode ekstraksi. Metode yang berbeda akan menghasilkan profil kimia yang berbeda pula. Wahjuningrum et al (2014), menyatakan bahwa ekstraksi kunyit dengan metode dekoksi selama 15 menit memberikan zona hambat yang lebih besar dibandingkan dengan metode ektraksi infusi dan maserasi terhadap pertumbuhan bakteri Edwardsiella tarda

Hasil pengamatan dan pengukuran zona bening yang terbentuk setelah dilakukan pengujian daya hambat ekstrak bawang hutan terhadap pertumbuhan bakteri aeromonas hydrophila terlihat bahwa, perlakuan metode maserasi dengan alkohol memberikan hasil yang paling besar dibandingkan dengan metode infusi, dekoksi dan maserasi dengan etanol. Hasil pengukuran zona bening dapat dilihat pada Gambar 1 dan Tabel 2.

Tabel 2 Hasil rata-rata zona hambat ekstrak

\begin{tabular}{cc}
$\begin{array}{c}\text { Metode ekstraksi } \\
\text { bawang hutan }\end{array}$ & $\begin{array}{c}\text { Rata-rata Zona bening terhadap } \\
\text { pertumbuhan Aeromonas hydrophila } \\
(\mathbf{c m} / \mathbf{m m})\end{array}$ \\
\hline Kontrol & 0 \\
Infusi & 0,5 \\
Dekoksi & 0 \\
Alkohol & 3,5 \\
Etanol & 1,5 \\
\hline
\end{tabular}

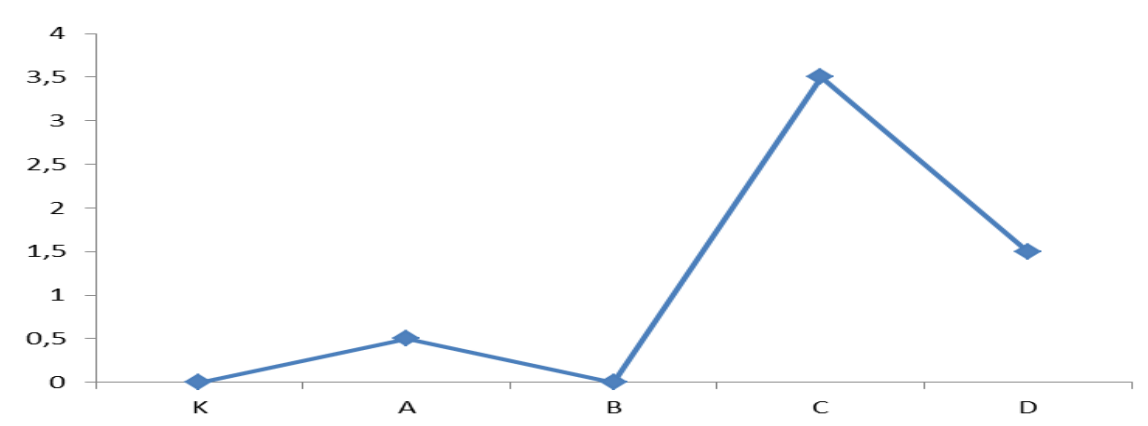

Gambar 1 Rata-rata zona bening ekstrak bawang hutan terhadap pertumbuhan bakteri Aeromonas hydrophila dengan metode ekstraksi berbeda yaitu A (infusi), B (dekoksi), C (maserasi alkohol), D (maserasi etanol) dan $\mathrm{K}$ (Aquades) 
Setelah diuji lanjut dengan uji Duncan's Multiple menggunakan SPSS 16 didapatkan hasil tidak berbeda nyata antara masing-masing perlakuan. Namun perlakuan metode maserasi dengan alkohol memberikan hasil yang paling besar dibandingkan dengan metode infusi, dekoksi dan maserasi dengan etanol, hal ini disebabkan adanya perbedaan ekstraksi sebab Salah satu faktor yang menyebabkan perbedaan yang bervariasi ini antara lain perbedaan metode ekstraksi.

Perbedaan hasil zona hambat ekstrak bawang hutan disebabkan kandungan kimia dari bawang hutan. Menurut Firdaus, 2014; Puspadewi et al., 2013, kandungan kimia umbi bawang dayak (E. palmifolia) seperti alkaloid, flavonoid, saponin, tannin, glikosid, tripenoid (), polifenol, kuinon, steroid monoterpenoid dan seskuiterpenoid. Flavanoid merupakan senyawa yang tidak tahan panas dan mudah teroksidasi pada suhu yang tinggi, hal ini terlihat pada hasil penelitian ini yaitu pada perlakuan infusi dan dekoksi yang menggunakan suhu $60^{\circ} \mathrm{C}$ didapat hasil terendah pada infusi, malahan pada perlakuan dekoksi tidak ada daya hambat terhadap pertumbuhan bakteri Aeromonas hydrophila. Dari hasil penelitian Safratilofa (2016) ekstrak daun kayu manis (Cinnamomum burmanni) dapat menghambat pertumbuhan bakteri $A$. hydrophila. Hal ini berhubungan dengan senyawa-senyawa yang terkandung dalam ekstrak daun kayu manis yang dapat menghambat pertumbuhan bakteri. Dari hasil uji fitokimia diketahui bahwa kandungan kimia dari ekstrak daun kayu manis adalah saponin, tanin, fenolik, flavonoid, alkanoid, steroid dan glikosida. Diduga bahwa kandungan kimia dari ekstrak daun kayu manis inilah yang dapat menghambat pertumbuhan bakteri. Senyawa-senyawa tersebut memiliki sifat antibakteri dengan mekanisme yang berbeda-beda.

Senyawa zat anti bakteri dari flavonoid dapat membentuk senyawa kompleks dengan protein ekstraseluler dan terlarut sehingga mampu merusak membran sel bakteri yang diikuti dengan keluarnya senyawa intraseluler (Nuria $e t$ al. 2009, Bobbarala, 2012). Falvonoid dapat menyebabkan terjadinya kerusakan permeabilitas dinding sel bakteri, mikrosom, dan lisosom sebagai hasil interaksi antara senyawa flavonoid dengan DNA bakteri (Lestari et al., 2013). Flavonoid memiliki mekanisme sebagai antibakteri dengan membentuk kompleks protein ekstraselular sehingga dapat merusak membran sel bakteri, menghambat sintesis DNA dan RNA, dan mengganggu metabolisme sel (Ngajow et al., 2013). Flavonoid yang mekanisme kerjanya mengganggu proses difusi makanan ke dalam sel sehingga pertumbuhan bakteri terhenti atau sampai bakteri tersebut mati. Dan Mekanisme antimikroba tanin berkaitan dengan kemampuan tanin membentuk kompleks dengan protein polipeptida dinding sel bakteri sehingga terjadi gangguan pada dinding bakteri dan bakteri lisis

Dari hasil penelitian ini, bahwa terdapat efek antibakteri pada ekstrak bawang hutan dengan cara infundasi dan dekoksi. Efek antibakteri tersebut diperkirakan diperankan oleh zat-zat aktif yang larut dalam air, sebab metode ekstraksi pada penelitian ini menggunakan pelarut air. Zat aktif yang terlarut dalam air yaitu tannin, triterpenoid, saponin dan flavanoid (Azima, 2004). Mekanisme antimikroba tanin berkaitan dengan kemampuan tanin membentuk kompleks dengan protein polipeptida dinding sel bakteri sehingga terjadi 
gangguan pada dinding bakteri dan bakteri lisis. Tanin juga memiliki sifat dapat menginaktifkan adhesin sehingga bakteri tidak dapat melekat pada sel inang dan menginaktifkan enzim protease.

Zona hambat terbesar diperlihatkan pada perlakuan ekstraksi menggunakan alkohol, hal ini mungkin disebabakan pelarut alkohol dapat menarik lebih banyak senyawa kimia dari ekstrak bawang hutan yang bersifat antimikroba. Zona hambat kedua terbesar pada ekstraksi menggunakan etanol. Efek antimikroba tersebut diperkirakan diperankan oleh zat-zat aktif yang larut dalam etanol.

\section{KESIMPULAN}

Kesimpulan dari penelitian yang telah dilakukan, bahwa terdapat perbedaan aktivitas antibakteri ekstrak bawang hutan dengan cara infusi, dekoksi, maserasi dengan alkohol dan maserasi dengan etanol. Diameter hambat lebih luas didapat pada maserasi dengan alkohol yaitu $3,5 \mathrm{~mm}$. Perlu dilakukan penelitian aktivitas antibakteri ekstrak bawang hutan dengan menggunakan bakteri lain yang bersifat patogen pada ikan budidaya, misalnya Edwarsiella, Streptococcus, atau Vibrio.

\section{DAFTAR PUSTAKA}

Angka SL. 2005. Kajian Penyakit Motile Aeromonas Septicemia (MAS) pada Ikan Lele Dumbo (Clarias sp.), Patologi, Pengobatan dan Pencegahannya dengan Fitofarmaka. Pascasarjana Institut Pertanian Bogor.

Amanda FR. 2014. Efektivitas Ekstrak Bawang Dayak (Eleutherine palmifolia) dalam Menghambat Pertumbuhan Bakteri Escherichia coli. Skripsi. Program Studi Pendidikan Dokter, Fakultas Kedokteran dan Ilmu Kesehatan, Universitas Islam Negeri Syarif Hidayatullah. Jakarta.

Bobbarala, V. 2012. Antimicrobial Agents. Intech, Croatia.

BPOM RI. 2010. Acuan Sediaan Herbal. Direktorat OAL. Jakarta. 5(1).

Cano-Gomez A, Bourne DG, Hall MR, Owens L, Hoj L. 2009. Molecular identification, typing and tracking of Streptococcus iniae in aquaculture systems: current methods and future prospects. Aquaculture 287:1-10.

Chrisolite B, Thiyagarajan S, Alavandi SV, Abhilash EC, Kalaimani N, Vijayan KK, Santiago TC. 2008. Distribution of luminescent Streptococcus iniae and their bacteriophages in a commercial shrimp hatchery in South India. Aquaculture 275:13-19.

Departemen Kesehatan RI. 2000. Parameter Standar Umum Ekstrak Tumbuhan Obat. Direktori Jenderal POM - DepKes RI. Jakarta.

Departemen Kesehatan RI. 2000. Acuan Sedian Herbal. Direktori Jenderal POM - DepKes RI. Jakarta.

Desrina, Arief T, Ambariyanto, Susiani S. 2006. Uji Keganasan Bakteri Vibrio pada Ikan Kerapu Macan (Epinephelus fuscoguttatus). Ilmu Kelautan. 11(3):119-125.

Firdaus, T. 2014. Efektivitas Ekstrak Bawang Dayak (Eleutherine palmifolia) dalam Menghambat Pertumbuhan Bakteri Staphylococcus aureus. Skripsi. 
Program Studi Pendidikan Dokter, Fakultas Kedokteran dan Ilmu Kesehatan, Universitas Islam Negeri Syarif Hidayatullah. Jakarta.

Garrity GM, Bell JA. Lilburn TG. 2004. Taxonomic outline of the prokaryotes bergey's manual ${ }^{\circledR}$ of systematic bacteriology, Second Edition. Michigan State University. doi:10.1007/bergeysoutline200405.

Ifesan BOT, Hamstain C, Mahabusarakam W, Voravuthikunchhai. 2009. Inhibitory Effect of Eleutherine americana Merr. Extract on Staphylococcus aureus Isolated from Food. Journal of Food Science. 74(1):31-36.

Kamillah SN. 2014. Efektivitas Ekstrak Umbi Bawang Sabrang (Eleutherine palmifolia (L.) Merr.) terhadap Pertumbuhan Bakteri Streptococcus pyogenes. Skripsi. Program Studi Pendidikan Dokter, Fakultas Kedokteran dan Ilmu Kesehatan, Universitas Islam Negeri Syarif Hidayatullah. Jakarta.

Kuntorini EM and Nugroho LH. 2010. Structural Development and Bioactive Content of Red Bulb Plant (Eleutherine americana); a Traditional Medicines for Local Kalimantan People. Biodiversitas. 11(2):102-106. DOI:10.13057/biodiv/d110210.

Lestari A, Mohammad J, I Nengah K. 2013. Daya hambat Ekstrak Daun Tembelek (Lantana camara L.) Terhadap Pertumbuhan Bakteri Escherichia coli. E-Jibiol. 1 : 42-49.

Lukistyowati, I dan Kurniasih. 2012. Pelacakan Gen Aeroslysin dari Aeromonas hydrophila pada Ikan Mas yang Diberi Pakan Ekstrak bawang Putih. Jurnal Veteriner. 13(1):43-50.

Naafi'ah FA, 2014. Efektivitas Ekstrak Umbi Bawang Dayak (Eleutherine palmifolia (L.) Merr.) dalam Menghambat Pertumbuhan Bakteri Streptococcus pyogenes. Skripsi. Program Studi Pendidikan Dokter, Fakultas Kedokteran dan Ilmu Kesehatan, Universitas Islam Negeri Syarif Hidayatullah. Jakarta.

Ngajow M, Jemmy A, Vanda SK. 2013. Pengaruh antibakteri ekstrak kulit batang matoa (Pometia pinnata) terhadap bakteri Staphylococcus aureus secara invitro. Jurnal Mipa Unsrat Online. 2(2):128-132.

http://ejournal.unsrat.ac.id/index.php/jmuo.

Nuria MC, Faizatun A, Sumantri. 2009. Uji Aktivitas Antibakteri Ekstrak Etanol Daun Jarak Pagar (Jatropha curcas L) terhadap Bakteri Staphylococcus aureus ATCC 25923, Escherichia coli ATCC 25922, dan Salmonella typhi ATCC 1408. Mediagro. 5(2):26-37.

Pratama MR. 2005. Pengaruh Ekstrak Serbuk Kayu Siwak (Salvadora persica) Terhadap Pertumbuhan Bakteri Streptococcus mutans dan Staphylococcus aureus dengan Metode Difusi Agar. Skripsi. Intitut Pertanian Bogor.

Puspadewi R, Putranti A., Rizka M. 2013. Umbi Bawang Dayak (Eleutherine palmifolia (L.) Merr.) Sebagai Herbal Antimikroba Kulit. Kartika Jurnal Imiah Farmasi. 1(1):31-37. 
Rey A, Verjan N, Ferguson HW, Iregul C. 2009. Pathogenesis of Aeromonas hydrophila strain KJ99 infection and its extracellular products in two species of fish. Veterinary Record 164: 493-499.

Saulnier D, Haffner P, Goarant C, Levy P, Ansquer D. 2000. Experimental infection models for shrimp vibriosis studies. Review. Aquaculture 191:133-144.

Safratilofa. 2016. Uji Daya Hambat Ekstrak Daun Kayu Manis (Cinnamomum burmanni) Terhadap Bakteri Aeromonas hydrophila. Jurnal Ilmiah Universitas Batanghari Jambi. $16: 98-103$

Soto-Rodriguez SA, Gomez-Gil B, Lozano R, Rio-Rodriguez RD, Dieguez AL, Romalde JL. 2012. Virulence of Streptococcus iniae responsible for the "Bright-red" syndrome in the pacific white shrimp Litopenaeus vannamei. Journal of Invetebrate Pathology 109:307-317.

Wahjuningrum D, Astrini R, Setiawati M. 2010. Pencegahan Aeromonas hydrophila pada benih ikan lele menggunakan bawang putih dan meniran. Jurnal Akuakultur Indonesia 9(2):93-103.

Wahjuningrum D, Ikhsan MN, Sukenda, Evan Y. 2014. Penggunaan ekstrak kunyit sebagai pengendali infeksi bakteri Edwardsiella tarda pada ikan lele. Jurnal Akuakultur Indonesia. 13 (1) : 1-10

Yogananth N, Bhaykyaraj R, Chanthuru A, Anbalagan T, Nila M. 2009. Detection of Virulence Gene in Aeromonas hydrophila Isolated from Fish Samles Using PCR Thecnique. Global Jurnal of Biotechnology and Biochemistry. 4(1):51-53. 